\title{
Information literacy training in AgroParisTech food studies
}

\author{
Agnès Grimal $^{a^{*}}$, Florence Dubois-Brissonnet $^{\mathrm{b}}$, And Elisabeth Dumoulin ${ }^{\mathrm{c}}$ \\ a AgroParisTech, Massy Centre Library, 1 avenue des Olympiades, F-91300 Massy, France \\ b AgroParisTech, UMR 1319 MICALIS, F-91300 Massy, France \\ c AgroParisTech, UMR 1145 Ingénierie Procédés Aliments, F-91300 Massy, France \\ ${ }^{*}$ Corresponding author \\ agnes.grimal@agroparistech.fr \\ TEL: +33(0)169935041 \\ FAX: +33(0)169200230
}

Received: 26 June 2014; Published online: 18 October 2015

Invited paper from the $3^{\text {rd }}$ International ISEKI_Food Conference - ISEKI_Food 2014 - Bridging Training and Research for Industry and the Wider Community - Food Science and Technology Excellence for a Sustainable Bioeconomy

\begin{abstract}
AgroParisTech professors and librarians in Food Science and Technology have developed information literacy instruction to help students find and use relevant information. The course trains students to develop information literacy competencies: to identify the information needed and define its nature and extent; to access the information with efficiency because they select and use methods, resources and retrieval systems most appropriate to the topic; to evaluate the used methods, information, and sources; to search, access and use information ethically and legally; to read, use and write bibliographic references.

AgroParisTech trains two kinds of students. For Higher Education students (engineering students), the training takes place at their arrival in AgroParisTech, including courses and practical classes: role and management of information in organizations; information on plagiarism; resources in environment, food science and technology; use of relevant tools and methods for searching in databases; reference writing.

For students attending a Master of Science, the training prepares them to produce a literature review. The curriculum includes: information about scientific integrity, plagiarism; information needed for a researcher; critical reading of a journal article; how to manage a literature review: resources used, information search with databases, full text access; reference writing.

The students will use these information literacy skills along their studies as well as in their future jobs.
\end{abstract}

Keywords: Competencies; Food studies; Information literacy

\section{Introduction}

Since the 1970s, the library world has been changing, with more information being accessible and quickly available online. However, finding the right information needs an appropriate methodology, and referencing and citing properly the sources are essential to retrieve the doc- uments. Students need instruction to select right resources, to find and use relevant information and to manage references. Indeed, in higher education, librarians have developed information literacy programmes integrated or not into academic programmes (Rader, 2002; Virkus, 2003). Students are faced with a mass of information, and they think that they can use the Internet 
alone to answer all their questions. Most of the time, they do not know about the specificities of the resources they use and if they are the most suited for their topics. This could lead to the collation of partial if not flawed information. There may be a lack of knowledge regarding the importance of information management in strategic decisions. Students may not appreciate how important information searches and uses could be to daily work. Several studies have tried to quantify and to qualify student ability in information literacy (e.g. Saunders, 2012; Diehm and Lupton, 2014). A study of Thirion and Pochet (2009) reveals that in Belgium, students entering higher education have low competencies in this domain. If information literacy in students entering AgroParisTech is not evaluated, the experience of the librarians and professors is consistent with the authors cited. For these reasons, twenty years ago, in the Ecole Nationale Supérieure des Industries Agricoles et Alimentaires (ENSIA), professors and librarians developed information literacy training for engineering and masters students. These courses were extended to new students when ENSIA joined two others Institutes to found the larger Institute AgroParisTech in 2007.

More generally, it was thought essential to train students in this field because those who do use the libraries correctly develop better competencies for studying (Fantin \& Heusse, 2012).

In this paper, the authors want to share their experiences and practices in information literacy instruction. They want to show the complexity of this training, which can explain the poor skills in this field observed among students (i.e. AgroParisTech and received students) they meet along studies (engineers, master's and PhD students). The importance of information all along the life will be also addressed.

\section{Integration of Information Literacy Instruction (ILI) in the AgroParisTech study programmes}

AgroParisTech is a Higher Education School, which trains in the areas of life sciences, agronomy, food technology and environment:
- Engineering students. The whole teaching curricula for engineers lasts five years after the French Baccalauréat (high school final examination). They spend the last three years in AgroParisTech.

- Masters students (M1 in $1^{\text {st }}$ year, M2 in $2^{\text {nd }}$ year). Some of them are coming from other French or International Universities.

- PhD students come from all around the world, for three years.

The engineering and masters students are involved in information literacy training to acquire competencies for both studies and future jobs. When they enter AgroParisTech, they have no business or research experience. It is fundamental to explain to them the importance of information in organizations or to give them a perfect knowledge of all the aspects of information during a research programme. Indeed, engineers and researchers need similar information literacy competencies but their information needs and aims are slightly different for work in a private company versus a research laboratory.

\subsection{Expected skills and training contents}

In many countries, information literacy competency standards for higher education are available (e.g. ACRL, 2000; ADBU, 2012). AgroParisTech uses such material as a basis for their courses in information literacy to:

- identify the information needed and define its nature and extent;

- access needed information with efficiency;

- evaluate methods, information and sources;

- search, access and use information ethically and legally;

- read, use and write bibliographic references.

To acquire information literacy competencies, the students must be trained on resources, on search and law of information, and on reference writing (e.g. in-text citation, listing of references). They also need methods to select the 
right information and to control its accuracy. For each competency, AgroParisTech librarians and professors have fixed the knowledge required for their students.

\section{To identify the information needed and define its nature and extent}

Figure 1 shows the sequences for finding information and data on a given topic. Often students use the resources available in libraries or online but they do not necessarily choose the best one according to their questions. Therefore, the training ensures that they ask the right research questions before searching for documents.

Firstly, the documents that are used depend on the kind of work. A scientific review mainly requires many papers while a general presentation requires books, reviews or syntheses.

Secondly, there are specific resources where to find each type of document. For papers, bibliographic databases will be the most relevant; for books, library catalogues are the best resources. Thirdly, the students must understand their topics and the issues to be investigated. If not, it is almost impossible to select a document because they are unable to determine its relevance for their work. This situation is particularly true for masters students who usually start with scientific articles, especially at the beginning of their research work. Alexander (2003) proposes a model of domain learning with three stages. Thompson and Lathey (2013) extend this model to an integrated model of information literacy. At the beginning of the studies, discipline knowledge and interest are low and the students have difficulties to distinguish which information is relevant. Along their studies, they become domain experts and acquire the ability to select the right information.

Moreover, the intended application of the information must be considered. A research laboratory and a quality control department do not use information in the same way. For this reason, during the module for engineering students, a professional presents strategic information in organizations/enterprises. Information flow and management for strategic decisions are very new aspects that students find very interesting and highly useful.
For masters students, the module emphasizes the different levels and types of information that are used during a research programme as a researcher has to search for, to exchange and to produce information. The different aspects of information are:

- Exhaustive search must be combined with scientific and technical intelligence throughout research. Specific questions on methods or physical data can be also searched;

- Researchers must be involved in scientific communities where they can participate in scientific discussions. The different ways of meeting other researchers (congress, online discussion group/forum, member of scientific society...) are mentioned;

- For publishing, the importance of journal selection is discussed: topic and/or impact factor will be chosen according to the objectives of the publication.

\section{To access needed information with efficiency}

Efficient search for information is possible with a proficient knowledge of resources. It is necessary to know the resource contents and the different tools to use them. These different aspects are presented such as:

- Resources and relevant secondary information access (catalogues, databases...);

- Resources available on campus during studies;

- Tools for database search: truncations, Boolean operators, proximity operators, and thesaurus. Personal accounts are created for saving searches and references;

- Ways of full text access.

This part of the training is based on exercises. The students search for references on bibliographic databases, CAB (Commonwealth Agricultural Bureaux International), Food Science and Technology Abstracts (FSTA), Environment complete and GreenFile (from EBSCO) or Pubmed. They make trials with author or 


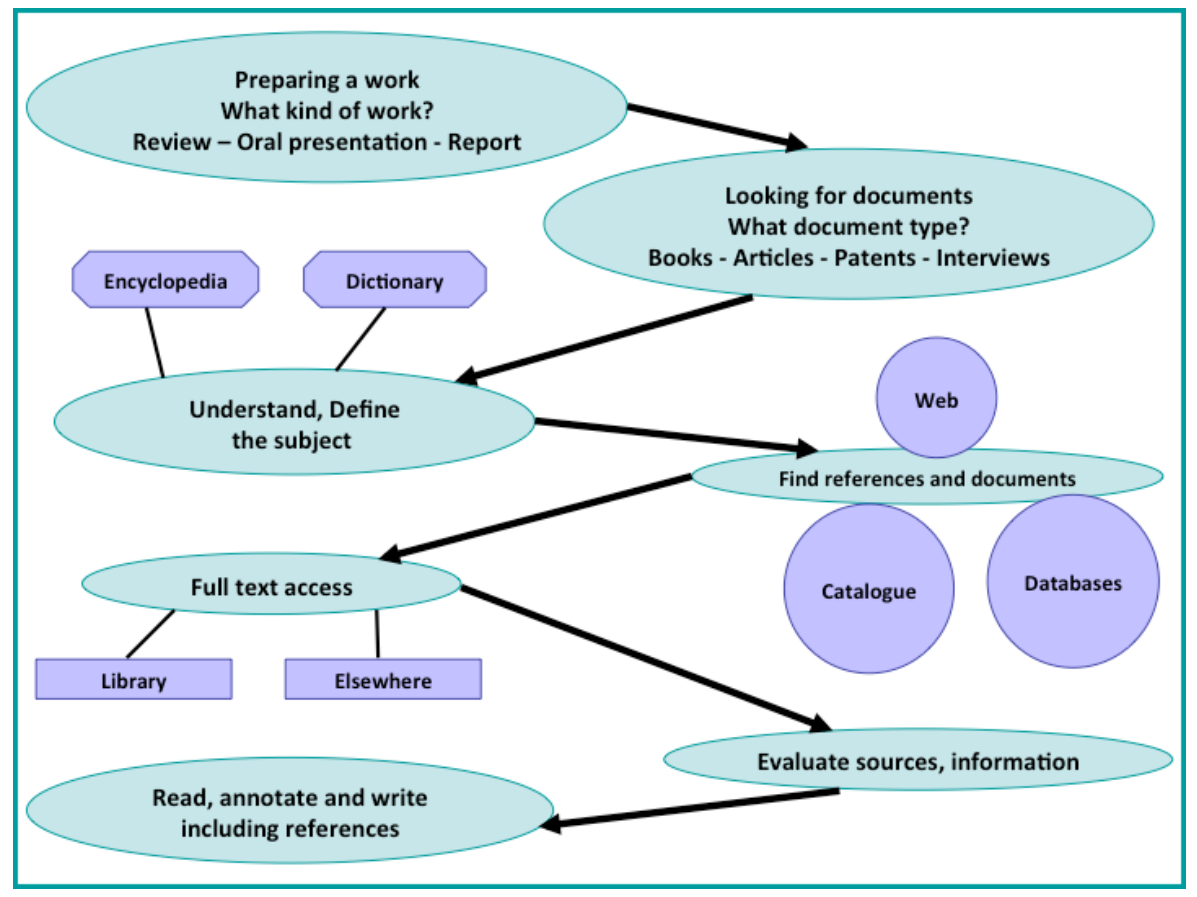

Figure 1: Methodology for defining and searching the information needed

subject search. In the module for engineering students, they must also answer six questions after the selection of the right resources among Ejournals directories, e.g. ScienceDirect, SUDOC catalogue (Système Universitaire de Documentation - a national catalogue) and AgroParisTech catalogue.

Examples of questions:

- Where in the Ile de France region can you find a 2013 issue of the journal, European Food Research and Technology?

- How can you obtain the full text of the following article: Maire M., Rega B., Cuvelier M.-E., Soto P., Giampaoli P. 2013. Lipid oxidation in baked products: Impact of formula and process on the generation of volatile compounds. Food Chemistry, Volume 141, Issue 4, p. 3510-3518.

AgroParisTech libraries are large working places with many available resources and services so during the information literacy training, a visit to the library is arranged for engineering students. Moreover, during masters student training, one particular bibliographic software for managing references (EndNote from Thomson Reuters) is introduced even if they do not use it immediately. It is a complementary tool for efficient use of information.

\section{To evaluate methods, information and sources used throughout one's search}

Students may not be familiar with the evaluation of the information and the methods to find it (e.g. completeness, veracity, accuracy, relevance, resources used). In working environments, the quality and accuracy of information is essential as strategic decisions can depend on it. Therefore, the students must know:

- the different information types (scientific, technical, technological, technical and economical, regulation, environmental and safety). The difficulty of information access is linked to its type. Scientific or regula- 
tory information is largely available while a technical and economic analysis is often confidential;

- the different document types (book, article, congress...) and the publishing methods (support, peer review system, open archive...) to identify the control and evaluation level of information. For example, domain experts evaluate the articles into the peer review journals while a book is the sole responsibility of authors;

- the available resources wherein the relevant information could be found.

In addition, masters students review and analyse a chosen scientific article with the help of a professor. They must read it critically and look for flaws in content to avoid doing the same later when writing their own papers.

\section{To search, access and use information ethically and legally}

More and more, young people use the Internet and plagiarize (Ma, Wan, \& Lu, 2008). But, when they are students, it is important that they know the rules about citation (reference to others' work) to avoid plagiarism. The importance of citations is explained not only to avoid plagiarism but also to show the bibliographic search and review made by the student and to facilitate document access for interested readers.

A professional with experiences in several companies presents to engineering students good practices for easier information flow. Information providers must always be cited and acknowledged. Access to legal and illegal information is also mentioned. Moreover, scientific integrity is discussed with masters students. Some examples of fraud and their reasons are presented.

\section{To read, use and write bibliographic references}

After a short lecture on how to write bibliographic references (in-text citations and lists of references), the students must write four or five references (book, article, conference paper, map, book chapter) using a guide.

\subsection{Organization of the modules}

The characteristics of the information literacy courses for engineering and masters curricula are detailed in Table 1, including lectures and practice hours. AgroParisTech chooses to teach information literacy with a single session. Hsieh, Dawson, Hofmann, Titus, and Carlin (2014) compare four pedagogical approaches (single or multi-session; review or not of a research guide before the class; active learning method with a worksheet to practice the search techniques). No differences of competencies acquired were found according to the teaching methods.

For engineering students, the duration of this teaching may appear short but we think, as do Thompson and Lathey (2013), that the students develop simultaneously domain knowledge and information literacy throughout their curriculum. The domain knowledge facilitates the information search and use, and information literacy helps to develop domain knowledge. Therefore, in AgroParisTech, information literacy will be asked and evaluated in other modules, in different ways (e.g. report, review, project, research, presentation) throughout the curricula.

\section{Conclusions}

The content and time for this information literacy training represent necessary bases for the students. They discover methods to find the right information, as clear and complete as possible. Information literacy competencies can be acquired during these specific courses but they are not sufficient. Many others approaches are possible and collaboration between librarians and professors is the best way to improve student interest and ability in this discipline (e.g. Pochet, Lepoivre, and Thirion, 2013; Thompson and Lathey, 2013). In AgroParisTech, all the courses on information literacy have been developed by librarians and professors. The AgroParisTech libraries participate in study programmes not only for this information literacy teaching but also for practical classes with professors and for helping students, researchers and teachers to find information. The library represents a quiet working and learning place for all the users, with available re- 
Information literacy training $\mid 131$

Table 1: Characteristics of information literacy courses for engineering and masters students at AgroParisTech

\begin{tabular}{|c|c|c|}
\hline & $\begin{array}{l}\text { Engineering Higher Education students } \\
\text { - year } 3 \text { in University - }\end{array}$ & $\begin{array}{l}\text { Master of Science students } \\
\text { - years 4-5 in University - }\end{array}$ \\
\hline Student level & $1^{\text {st }}$ year study in AgroParisTech & $\begin{array}{l}\text { M1 } 1^{\text {st }} \text { year Master } \\
\text { M2 (for students from other universities } \\
\text { without AgroParisTech M1 training) }\end{array}$ \\
\hline Location & $1^{\text {st }}$ year study centre & Massy Food Science and Technology centre \\
\hline Date & First month & $\begin{array}{l}\text { M1 January, before laboratory training } \\
\text { M2 during the first term }\end{array}$ \\
\hline \multirow[b]{2}{*}{$\begin{array}{l}\text { Number of } \\
\text { students }\end{array}$} & 360 & $\begin{array}{l}\text { M1 around } \mathbf{2 0} \\
\text { M2 around } \mathbf{1 0}\end{array}$ \\
\hline & $\begin{array}{l}\text { - } 2 \text { groups of } 180 \text { with } 1 \text { h30 in lecture hall } \\
\text { - } 12 \text { groups of } 30 \text { with } 2 \text { h30 in computer } \\
\text { rooms ( } 1 \text { computer for } 2 \text { students })+ \\
\text { 0h30 for library visit } \\
\text { - } 24 \text { groups of } 15 \text { with } 1 \text { h3 } 30 \text { in computer } \\
\text { rooms ( } 1 \text { computer per student) }\end{array}$ & $\begin{array}{l}\text { M1 - } 1 \text { group of } 20 \text { with } 5 \mathrm{~h} 30 \\
\quad-2 \text { groups of } 10 \text { with } 23 \mathrm{~h} 30 \\
\text { M2 } 1 \text { group of } 10 \text { with } 8 \mathrm{~h} \\
\text { All in computer rooms } \\
\text { (1 computer per student) }\end{array}$ \\
\hline $\begin{array}{l}\text { Teaching time } \\
\text { per student }\end{array}$ & $\mathbf{6 h}(1 \mathrm{~h} 30+2 \mathrm{~h} 30+0 \mathrm{~h} 30+1 \mathrm{~h} 30)$ & $\begin{array}{l}\text { M1 } \mathbf{2 9 h}(14 \mathrm{~h}+15 \mathrm{~h} \text { personal work }) \\
\text { M2 } \mathbf{8 h}\end{array}$ \\
\hline Teaching hours & $75 \mathrm{~h}-7$ teachers & $\begin{array}{l}\text { M1 } \mathbf{2 9 h}-1 \text { teacher }+1 \text { for article analysis } \\
\text { M2 } \mathbf{8 h}-1 \text { teacher }\end{array}$ \\
\hline $\begin{array}{l}\text { Materials: } \\
\text { paper copies } \\
\text { and online } \\
\text { documents }\end{array}$ & $\begin{array}{l}\text { - Bibliographic reference guide } \\
\text { - Slides }\end{array}$ & $\begin{array}{l}\text { M1 information for researchers, reading } \\
\text { and writing publication, bibliographic } \\
\text { reference guide, slides } \\
\text { M2 as M1 + literature review guide }\end{array}$ \\
\hline Exam & No exam & $\begin{array}{l}\text { M1 students propose a bibliographic } \\
\text { search (selection of databases, keywords, } \\
\text { articles) on their laboratory training topic } \\
\text { M2 they write a literature review on their } \\
\text { laboratory training topic }\end{array}$ \\
\hline
\end{tabular}


sources and services.

The information literacy competencies acquired during studies will be extended all along the life with significant time spent to look for information. The development of the information society and the knowledge economy, and lifelong learning must be considered to ensure that students will share data and experience, will communicate ethically and legally to be actors of the society (Pochet et al., 2013). Johnston and Webber (2003) think that information literacy is a key discipline of the information society. They develop a model of the information literate student in the changing information society and even speak of the information literate university where all the members would become information literate. Even if the universities have not completely developed this model, it is evident that students must be information literate to develop their knowledge in a constantly changing world.

\section{Acknowledgements}

J. Dequéant, D. Gasparotto, A. Lesueur, Y. Maresse and M.-C. Pattier, librarians, P. Cansell, consultant, are involved in the training of Engineering Higher Education students.

Prof. Marie-Noëlle Maillard analyses the scientific article with the masters students.

The authors acknowledge Will Raiser for the English language correction.

\section{References}

ACRL. (2000). Association of College and Research Libraries. Information literacy competency standards for higher education. Chicago: American Library Association. Retrieved from http://www.ala.org/acrl/ standards/informationliteracycompetency

ADBU. (2012). Association des Directeurs \& Personnels de Direction des Bibliothèques Universitaires et de la Documentation. Référentiel de compétences informationnelles: pour réussir son parcours de formation dans les établissements d'enseignement supérieur. Paris: ADBU. Retrieved from http : / / adbu . fr / wp content / uploads / 2013/02/R\% C3\% A9f\%
C3\% A9rentiel- ADBU - 2012-165X235cm3.pdf

Alexander, P. A. (2003). The development of expertise: the journey from acclimation to proficiency. Educational Researcher, 32(8), 10-14. doi:10.3102/0013189X032008010

Diehm, R.-A. \& Lupton, M. (2014). Learning information literacy. Information Research - An International Electronic Journal, 19(1). Retrieved from http://www . informationr.net/ir/19-1/paper607.html

Fantin, R. \& Heusse, M. (2012). Emprunt en bibliothèques universitaires et réussite aux examens en licence. Toulouse: Université de Toulouse. Retrieved from http : / / bibliotheques . univ - toulouse . fr / fichiers / etude - emprunt - en - bu - et - reussite - en licence20121221.pdf

Hsieh, M. L., Dawson, P. H., Hofmann, M. A., Titus, M. L., \& Carlin, M. T. (2014). Four pedagogical approaches in helping students learn information literacy skills. Journal of Academic Librarianship, 40(3-4), 234-246. doi:10.1016/j.acalib.2014.03.012

Johnston, B. \& Webber, S. (2003). Information literacy in higher education: a review and case study. Studies in Higher Education, 28(3), 335-352. doi:10.1080/ 03075070309295

Ma, H. J., Wan, G., \& Lu, E. Y. (2008). Digital cheating and plagiarism in schools. Theory Into Practice, 47(3), 197-203. doi:10.1080/ 00405840802153809

Pochet, B., Lepoivre, P., \& Thirion, P. (2013). Littérature scientifique et formation à l'information, la situation des bioingénieurs à Gembloux Agro-Bio Tech (ULg). (synthèse bibliographique). Biotechnologie, Agronomie, Société et Environnement, 17(1), 118-130.

Rader, H. B. (2002). Information literacy 19732002: a selected literature review. Library Trends, 51(2), 242-259.

Saunders, L. (2012). Faculty perspectives on information literacy as a student learning outcome. Journal of Academic Librarianship, 38(4), 226-236. doi:10.1016/j.acalib. 2012.06.001

Thirion, P. \& Pochet, B. (2009). Information literacy in students entering higher education 
Information literacy training 133

in the French speaking community of Belgium: lessons learned from an evaluation. IFLA journal, 35(2), 152-170.

Thompson, G. B. \& Lathey, J. W. (2013).

An integrated model of information literacy, based upon domain learning. Information Research - An International Electronic Journal, 18(3). 8th International Conference on Conceptions of Library and Information Science, Copenhagen, DENMARK, AUG 19-22, 2013. Retrieved from http:// www . informationr . net / ir / $18-3$ / colis / paperC02.html

Virkus, S. (2003). Information literacy in Europe: a literature review. Information Research An International Electronic Journal, 8(4). Retrieved from http://www.informationr. net/ir/8-4/paper159.html 